Revista Brasileira de Meteorologia, v.24, n.1, 48-55, 2009

\title{
RELATIONSHIP BETWEEN THE SOUTHERN ANNULAR MODE AND SOUTHERN HEMISPHERE ATMOSPHERIC SYSTEMS
}

\author{
MICHELLE SIMÕES REBOITA, TÉRCIO AMBRIZZI AND ROSMERI PORFÍRIO DA ROCHA
}

\author{
Universidade de São Paulo \\ Instituto de Astronomia, Geofísica e Ciências Atmosféricas \\ Departamento de Ciências Atmosféricas, Cidade Universitária, São Paulo, SP
}

reboita@model.iag.usp.br, ambrizzi@model.iag.usp.br, rosmerir@model.iag.usp.br

Received March 2008 - Accepted December 2008

\begin{abstract}
Seasonal relationship between the Southern Annular Mode (SAM) and the spatial distribution of the cyclone systems over Southern Hemisphere is investigated for the period 1980 to 1999. In addition, seasonal frontogenesis and rainfall distribution over South America and South Atlantic Ocean during different SAM phases were also analyzed. It is observed that during negative SAM phases the cyclone trajectories move northward when compared to the positive one, and in the South America and South Atlantic sector there is intense frontogenetic activity and positive anomaly precipitation over the Southeast of the South America. In general, SAM positive phase shows opposite signals.

Key-Words: SAM, cyclones density, frontogenetic function, southeast South America

\section{RESUMO: RELAÇÃO ENTRE O MODO ANULAR SUL E OS SISTEMAS ATMOSFÉRICOS NO HEMISFÉRIO SUL}

A relação sazonal entre o Modo Anular Sul (Southern Annular Mode - SAM) e a distribuição espacial dos sistemas ciclônicos sobre o Hemisfério Sul foi investigada no período de 1980 a 1999. Também foram analisados os padrões sazonais de frontogêneses e de distribuição de precipitação, sobre a América do Sul e oceano Atlântico Sul, durante as diferentes fases da SAM. Na fase negativa da SAM foi observado que a trajetória dos ciclones em todo o Hemisfério Sul move-se para norte, comparada à fase positiva, e que no setor da América do Sul e Atlântico Sul há intensa atividade frontogenética e anomalias positivas de precipitação na costa sudeste da América do Sul. Em geral, na fase positiva da SAM são observadas condições inversas.
\end{abstract}

Palavras-Chave: SAM, densidade de ciclones, função frontogenética, sudeste da América do Sul

\section{INTRODUCTION}

The Southern Annular Mode (SAM) is the major mode of variability of the extratropical circulation in the Southern Hemisphere and is characterized by zonally symmetric or annular structures, with geopotential height perturbations of opposing signs in Antarctica and in the surrounding zonal ring centered near $45^{\circ}$ latitude (Thompson and Wallace, 2000a). The SAM also called Antarctic Oscillation (Gong and Wang, 1999) and High-Latitude Mode (Rogers and Van Loon, 1982) is barotropic and appears throughout the year in the troposphere, but it amplifies with height upward into the stratosphere during the late spring, period in which the strength of the zonal flow is conducive to strong planetary wave-mean flow interaction (Thompson and Wallace, 2000a). Yu and Hartmann (1993) suggested that the maintenance of the SAM is due to the internal dynamics of the atmosphere through interactions with the eddy momentum fluxes. On the other hand, as mentioned by Thompson (2007) there is yet no single widely accepted theory as to why annular modes are so predominant in Earth's atmosphere.

According to Thompson and Wallace (2000a) the SAM can be observed through the leading empirical orthogonal function (EOF) in many atmospheric fields (for example, sea level pressure, surface temperature, geopotential height and zonal wind). In order to understand the variability of SAM and 
its possible connection with southern climatic anomalies in detail, an index was built by the Climate Prediction Center (CPC - NOAA) using EOF analysis in the monthly mean $700 \mathrm{hPa}$ height anomalies poleward $20^{\circ} \mathrm{S}$, for the period of 1979 to 2000 . Daily and monthly SAM indices are constructed by projecting the daily and monthly mean $700 \mathrm{hPa}$ height anomalies onto the leading EOF mode. It is worthy mentioning that both time series are normalized by the standard deviation of the monthly index (1979-2000 base periods). Positive (negative) values of the SAM index are associated with negative (positive) height anomalies over Antarctica and positive (negative) anomalies at midlatitudes. Similar definition to the SAM index was employed by Thompson and Wallace (2000 a, b). In their analysis from 1968 to 1997 they found a trend toward the positive phase of the SAM, but any clear seasonality.

There have not been many studies trying to understand the relationship between the weather systems in the South America and the SAM. Silvestri and Vera (2003) examined the relation between the SAM and the precipitation in the southeast South America. The authors observed that in particular during spring, SAM positive (negative) phases are associated with the intensification of an upper-level anticyclonic (cyclonic) anomaly, weakened (enhanced) moisture convergence and decreased (increased) precipitation over southeast South America. However, most of their discussion was in an El Niño/Southern Oscillation (ENSO) context. Carvalho et al. (2005) noted a strengthening (weakening) of the subtropical high-level jet in the SAM negative (positive) phases in both hemispheres and also the weakening (strengthening) of the highlevel polar jet, particularly in the Southern Hemisphere during negative (positive) SAM events. These authors also observed higher extratropical cyclone occurrence in the SAM negative phase in lower latitudes, suggesting that it occurs associated to displacement of the subtropical jet toward the equator during negative SAM events, which favors the cyclones to initiate and dissipate at lower latitudes.

The objective of this study is to identify the relationship between the seasonal spatial variability of the cyclones distribution in the Southern Hemisphere and the frontogenetic regions in South America and South Atlantic Ocean in different SAM phases. Some discussion about the rainfall distribution over southeast South America will also be presented. This paper is divided in the following sections: Section 2 describes the data sources used and the methodology; Section 3 discusses the results and the last section presents the final comments.

\section{DATA AND METHODOLOGY}

To identify the relationship between the SAM and the weather systems spatial distribution in the Southern Hemisphere and in particular over southeast South America a frontogenetic function and cyclones density maps are calculated from 1980 to 1999 period. The frontogenetic function (F) due to horizontal deformation and divergence fields was calculated using daily data based in the definition of Petterssen (1956):

$$
\mathrm{F}=-\frac{1}{2}|\nabla \mathrm{T}|(\mathrm{D} \cos 2 \gamma+\delta)
$$

where $|\nabla T|$ is the magnitude of the horizontal temperature gradient, $\mathrm{D}$ is the horizontal deformation, $\gamma$ is the angle between the dilatation axis and the temperature gradient and $\delta$ is the horizontal divergence. When $\mathrm{F}$ is positive the isotherms tend to converge, a process referred to as frontogenesis; while frontolysis occurs when $\mathrm{F}$ is negative. An example of the frontogenetic function application to the Southern Hemisphere is given in Satyamurty and Mattos (1989). To find and track the cyclones and anticyclones an algorithm developed by Murray and Simmons (1991 a, b) and briefly described in Pezza and Ambrizzi (2003) was used. This algorithm identifies the cyclones (anticyclones) through of the minima (maxima) of the sea level pressure. All cyclones and anticyclones identified with lifetime equal or higher than 24 hours (without considering a threshold for intensity) are included in the calculus density. The density correspond to the number of systems/unit area found in a particular region and is calculated by adding contributions from all sampled positions. The atmospheric field used in the cyclones and anticyclones track is the sea level pressure with 12 hours of temporal resolution. For the frontogenetic function it is needed air temperature and zonal and meridional wind at $850 \mathrm{hPa}$ with 1-day temporal resolution. The data were obtained from the National Center for Environmental Prediction - National Center for Atmospheric Research (NCEP-NCAR) reanalysis (Kalnay et al. 1996). Although the NCEP-NCAR reanalysis dataset is available from 1948, the period 1980 to 1999 used here was chosen because the data quality was much improved after the satellite era in 1979 (Kanamitsu et al., 2002).

Once obtained the frontogenetic function and the cyclone and anticyclone densities, seasonal composites according to the SAM phase were produced. The definition of the phase is based on the calculation of the standard deviation of the monthly SAM index obtained at the Climate Prediction Center webpage from 1980 to 1999. Values below (above) one standard deviation $( \pm \sigma)$ will be considered negative (positive) SAM phase and values between $\pm \sigma$ as neutral phase (Figure 1). The standard deviation value of the SAM time series from 1980 to 1999 is equal 1.0. Positive (negative) values of the SAM index are associated with negative (positive) height anomalies over Antarctica and positive (negative) anomalies at midlatitudes. Precipitation 
seasonal anomalies were based on the monthly precipitation data obtained from the Global Precipitation Climatology Project (GPCP - Adler et al., 2003). Precipitation monthly anomalies from 1980 to 1999 were determined and the seasonal mean of the anomalies was determined according to the different SAM phases. To verify the statistical significance of the anomalies at the $10 \%$ level (confidence of the $90 \%$ ) at test was calculted (Wilks, 2006).

\section{RESULTS}

Figure 1 shows the SAM index for the period of 1980 to 1999 and Table 1 indicates the number of months where the negative (-), neutral (0) and positive (+) SAM phases were predominant in each season during this period. In total, 37 months had negative index (below one $\sigma$ ) and 38 were positive (above one $\sigma$ ). This result suggests that there is not any preferential SAM phase along the 20 years period used here. However, from Figure 1 it is observed that there is a small positive phase tendency from 1993 to 2000 which agrees with some other studies (Thompson and Wallace 2000b, Marshall 2003). The seasonal SAM phase variability is small where the difference between the season with maximum frequency of negative phase occurrence (winter) and the minimum (spring) is of 5 months. For the positive phase the difference is even smaller ( 3 months) between the maximum (winter) and minimum (autumn). Therefore based on Figure 1 and Table 1 one could conclude that there is not any preferential season for any SAM phase in the analyzed period which is in agreement with Thompson e Wallace (2000b).

In order to identify the relationship between the frontogenetic regions over southeast South America and the SAM a frontogenetic function was calculated for the period 1980 to 1999. Composites of the SAM phases for each season are shown

Table 1 - The number of the selected months with negative (-), neutral (0) and positive (+) SAM phases for all seasons between 1980 to 1999 period.

\begin{tabular}{cccc}
\hline Seasons & SAM (-) & SAM (0) & SAM (+) \\
\hline Summer & 9 & 41 & 10 \\
Autumn & 9 & 43 & 8 \\
Winter & 12 & 37 & 11 \\
Spring & 7 & 44 & 9 \\
\hline Total & $\mathbf{3 7}$ & $\mathbf{1 6 5}$ & $\mathbf{3 8}$ \\
\hline
\end{tabular}

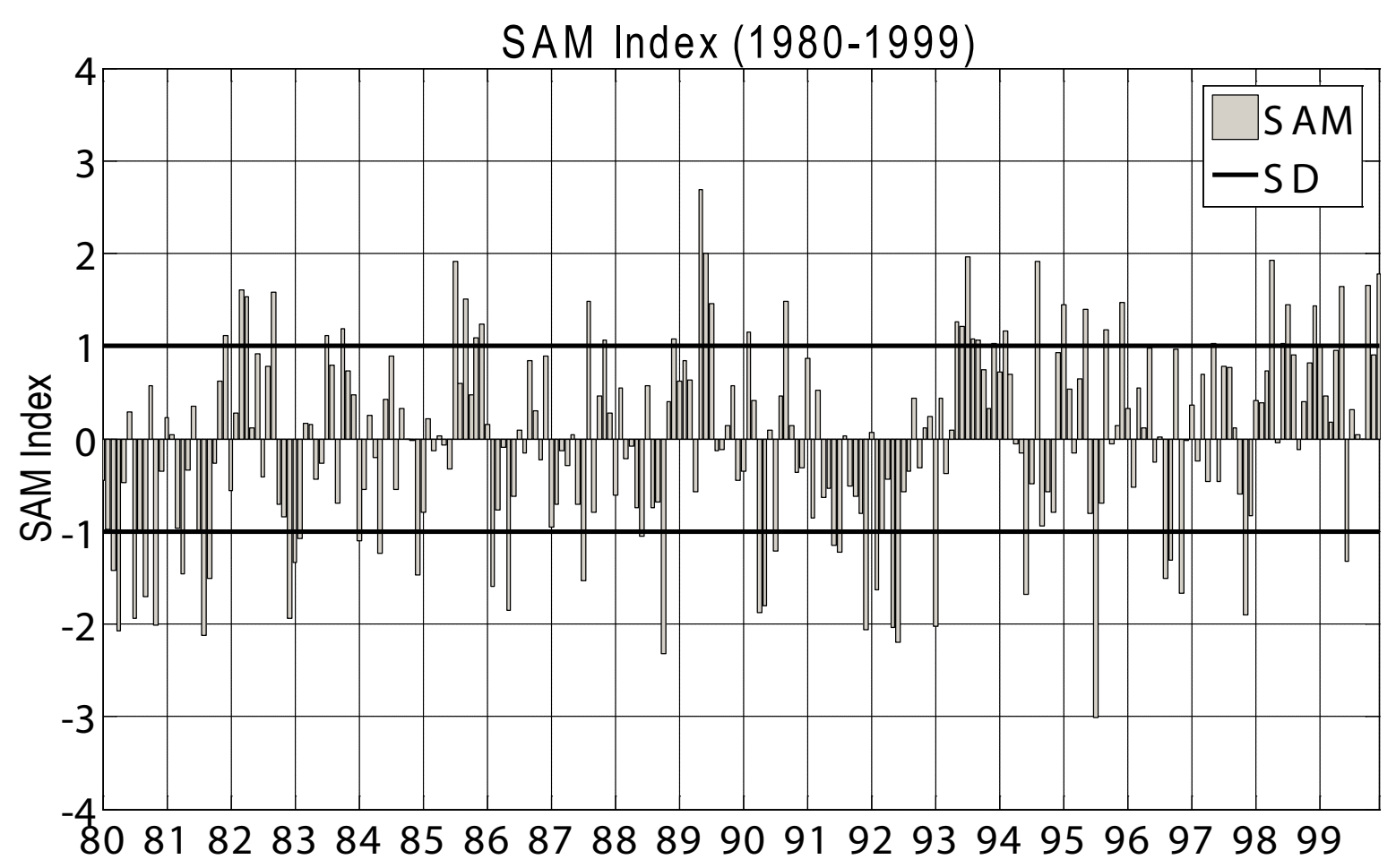

Figure 1 - Monthly SAM Index from 1980 to 1999 and standard deviation (SD - continuous line). 
in Figure 2. For the SAM (-) there are frontogenetic conditions in all seasons (Figure 2a-d) over Southern Brazil, Uruguay and parts of central and northeast Argentina as well as a large region over the South Atlantic Ocean. Frontolysis is observed over the north (all seasons) and south (spring and summer) portions of Chile and during the whole year in the northeast of Brazil. During the SAM neutral phase (Figure 2e-h) there is a clear decrease in the intensity of the frontogenetic areas, particularly over the ocean during the autumn and winter seasons. In comparison with SAM (-), there is less frontogenetic conditions during autumn and winter for the SAM (+) over the southeast South America and South Atlantic Ocean (Figure 2i-1). In the spring and summer there is also less frontogenetic conditions in the SAM (+), but these seasons are more similar to the SAM (-) than autumn and winter. The general seasonal patterns of the frontogenetic and frontolysis fields presented in Figure 2 show some similarities with the climatological analysis done by Satyamurty and Mattos (1989), though they have only used 5 years of data and each season was represented by just one month.

The Southern Hemisphere composite of extratropical cyclone density for each season and SAM phase is shown in
Figure 3. During the SAM (-) (Figure 3a-d) the cyclogenetic belt around the Antarctic continent is more scattered than for the neutral (Figure 3e-h) and positive phase (Figure 3i-l) and displaced to the north. In fact, cyclone density figures for SAM (+) (Figure 3i-l) indicate that the systems are closer to the Antarctic continent than during the neutral phase (Figure 3e-h) when they are localized between both phases. The mean extratropical cyclone behavior obtained by Simmonds and Keay $(2000 \mathrm{a}, \mathrm{b})$ is quite similar to the cyclone pattern of the neutral and positive SAM phases observed in Figure 3. However the SAM (-) shows higher cyclone density at midlatitudes and it indicates a preferential genesis region slightly to the north during this phase. In general the results suggest that the number of cyclones as well as the seasonal variability do not show any significant difference among the phases and it is only the position that is affected.

To complete the analysis, the Southern Hemisphere anticyclone density (figure not shown) was also done. The results indicate that the position of the anticyclone belt is also displaced to north during the SAM (-) in relation to SAM (0) and SAM $(+)$.
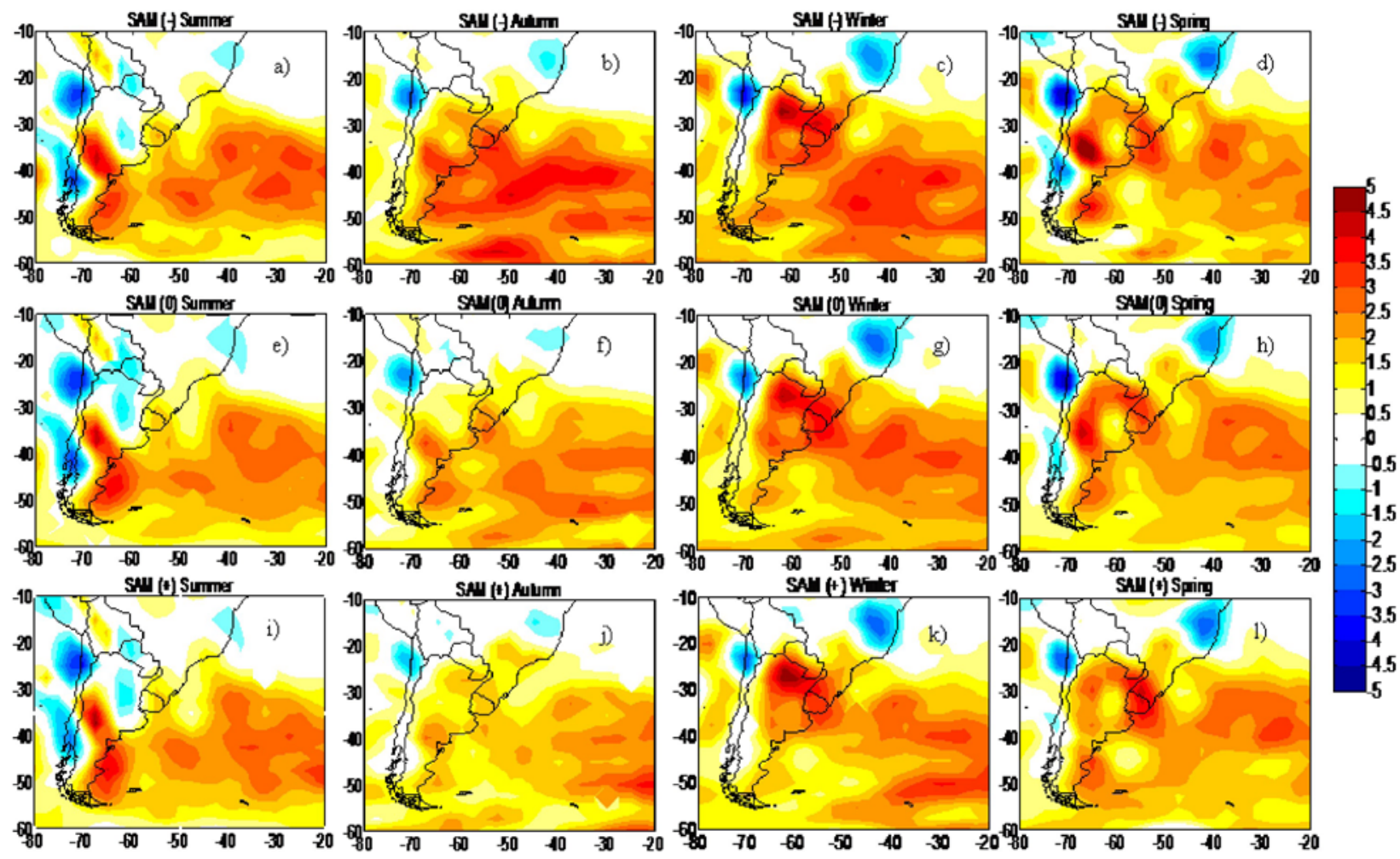
. 
Once the position of the main trajectories of the cyclone systems is influenced by the SAM phases, particularly during its negative occurrence, the precipitation distribution over South America may also be modified. In order to verify such relationship the seasonal precipitation anomalies for different SAM phases are shown in Figure 4. During the SAM (-), positive precipitation anomalies (Figure $4 \mathrm{a}-\mathrm{d}$ ) are observed over the Southern Brazil, Uruguay and central-north Argentina mainly in the summer and autumn. The maximum rainfall occurs during autumn extending all over the southern part of South America. This pattern is in agreement with the frontogenetic conditions shown in Figure 2. In the summer (Figure 4a) one can see large positive precipitation anomaly over the Southern Brazil. This result agrees with the teleconnectivity analysis performed by Carvalho et al (2005) where they related Southern Hemisphere teleconnection patterns with different SAM phases. They found that for negative SAM the subtropical jet is strengthened and it drifts equatorward favoring the propagation of the transient systems in this region. On the other hand, it is also worthy noting that negative precipitation anomalies are observed over the climatological position of the South Atlantic Convergence
Zone (SACZ), a region of maximum precipitation activity during the South American monsoon period (Carvalho et al 2004, Vera et al 2006). It is possible that in the presence of more cyclones over the Southern Brazil the moisture transport over the SACZ region is diminished, weakening the moisture flux convergence over southeastern Brazil and restricting the moisture transport mainly over La Plata basin (Liebmann et al. 2004; Herdies et al. 2002).

For the SAM $(+)$, the general precipitation pattern is almost opposite to the negative phase (Figure 4e-h), particularly during the autumn season when negative precipitation anomalies are observed over the southern Brazil and weak positive ones are seen over the southeast. This seesaw pattern is also seen during the summer when positive precipitation anomalies are observed over the central and north parts of Brazil. In this case the SACZ is displaced northward from its climatological position. The teleconnection analysis from Carvalho et al (2005) showed that during the positive SAM phase the subtropical waveguide seems to be displaced southward which is also in agreement with the cyclone density maps depicted in Figure 3i-l. Therefore, it is suggested that less cyclones cross the south of South America
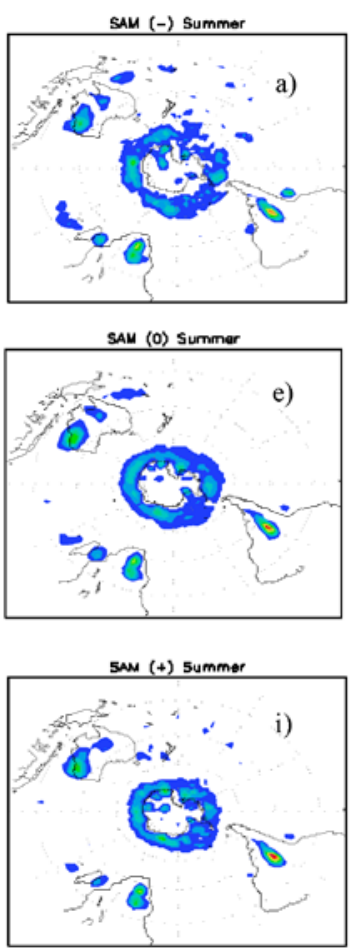

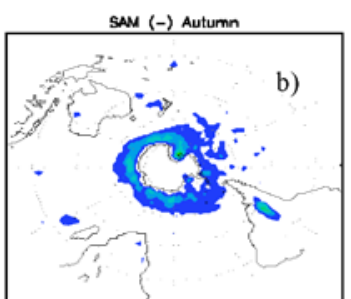

SAM (D) Autumn
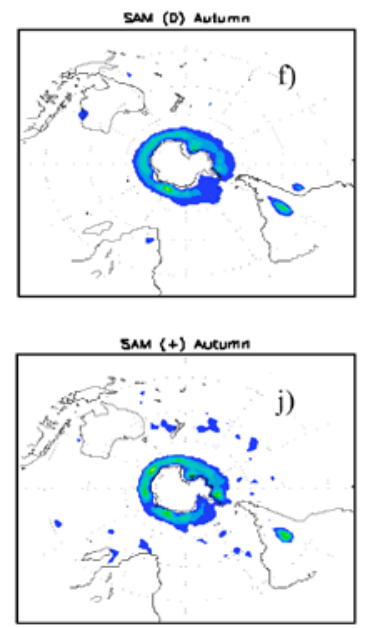

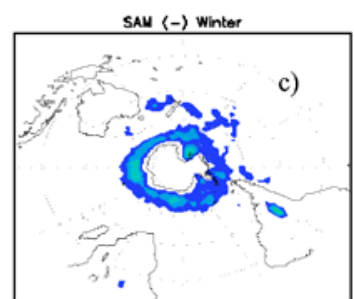

SAM (0) Winter

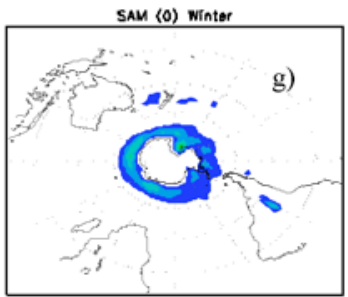

$\operatorname{san}(+)$ winter

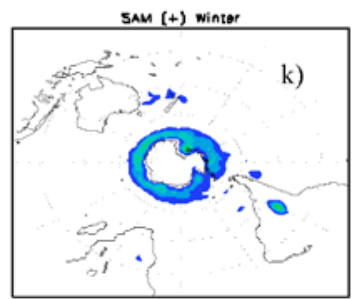

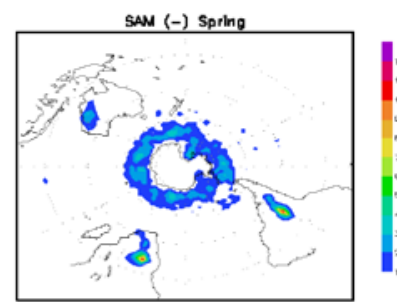
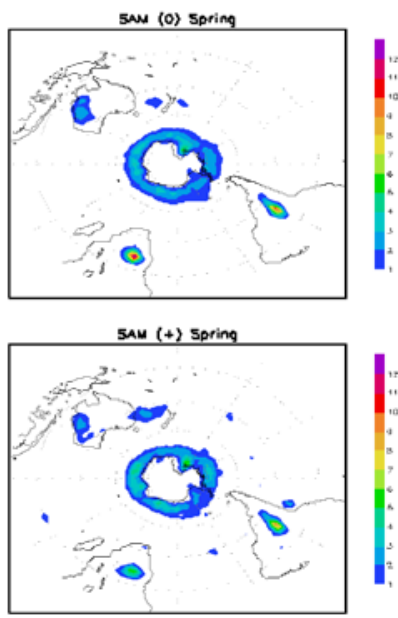

Figure 3 - Similar to figure 2, but for cyclones density maps [the mean number found in a 103 (deg lat) 2 area]. The values were multiplied by 103 (deg lat)-2. 
in this period. The frontogenetic maps shown by the Figure $2 \mathrm{i}-\mathrm{j}$ also indicate a much weaker frontogenesis pattern, particularly during the autumn season. In general, negative precipitation anomalies are observed in the southern part of South America during the SAM $(+)$ and positive ones in the northern part with an intensity smaller than that obtained from the negative phase.

\section{CONCLUSIONS}

The relationship between the Southern Hemisphere cyclones spatial variability and the SAM different phases was investigated in this study. Also, the main frontogenetic regions as well as the rainfall distribution over southeast South America and how they are modified during different SAM phases were analyzed.

The SAM phases analysis from 1980 to 1999 indicated that there is not any preferential season for each SAM phase. However, a positive phase trend was observed from 1993 to 2000. The seasonal composite analyses of frontogenetic regions and rainfall distribution over southeast South America and their relationship with the cyclones for positive and negative SAM phases showed interesting results.

The seasonal frontogenetic maps calculated for each SAM phase indicated that the most intense values are found during the SAM (-) with a maximum in the autumn season. It is also during this phase that the cyclone density is more scattered and displaced to the north when compared to the SAM $(+)$ which shows strong cyclone concentration around the Antarctic continent. The analysis of teleconnection patterns with different SAM phases for the austral summer done by Carvalho et al (2005) had already suggested that during SAM (-) the subtropical jet which works as a waveguide drifts northward and therefore favors the cyclone propagation towards the southeast of South America. On the other hand, the cyclone path moves southward for the SAM (+). These features have an impact on the seasonal precipitation anomaly patterns observed during both SAM phases. For the negative one, positive precipitation anomalies are seen all over the southern part of South America during autumn and more concentrated around southern Brazil and northern Argentina during the summer. In particular, it is noted that negative precipitation anomalies prevail in the north and southeast part of the continent. It seems that the South American monsoon activity and therefore the SACZ is weaker during the summer when SAM (-) occurs. It is possible that the increase of cyclone activity over southern Brazil favors the transport of warm and humid air from the Amazon basin towards this region through the low level jet (LLJ) east of the Andes (Marengo et al 2004 and references therein). Liebmann et al. (2004) have recently shown the relationship between the South American LLJ and extreme precipitation events over subtropical South America during austral summer. Using lead and lag composites of circulation for rainfall anomalies associated with the jet, they suggested that on a daily time scale, a preference for rain (no rain) in the SACZ should agree with a weak (strong) jet and dry (wet) conditions downstream of it. The precipitation patterns observed in the composites made in this study seem to agree with the above description. On the other hand, during SAM $(+)$ periods there are negative anomalies over the southern
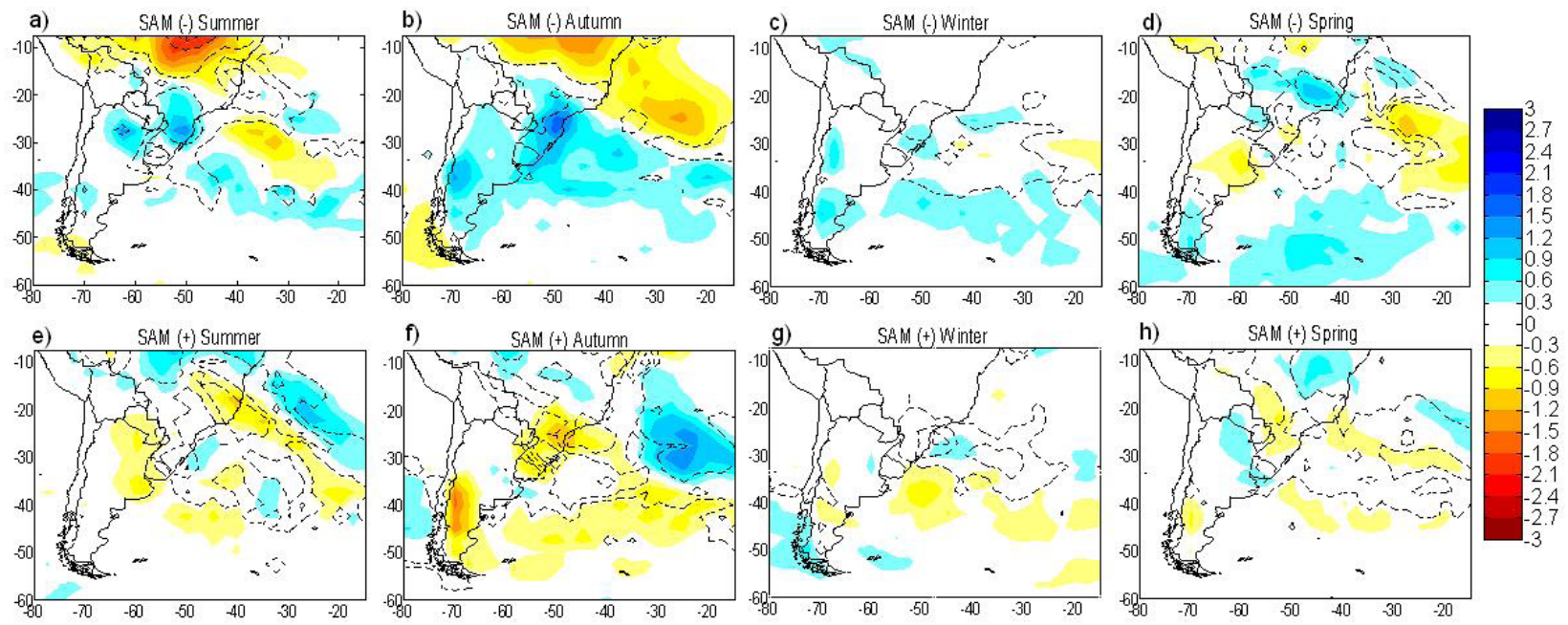

Figure 4 - Precipitation anomaly for the negative (-) and positive (+) SAM phases during the summer (a, e), autumn (g, f), winter (c, g) and spring $(d, h)$ seasons in the period 1980-1999. Dot lines indicate areas with statistically significant anomalies at the confidence level of $90 \%$. 
part of South America and positive to the north, where in this case the SACZ is displaced northward from its climatological position. In fact, during this phase the southern part of the South America and South Atlantic Ocean present negative anomalies or neutral condition for all seasons, suggesting weak cyclone activity there. Some of the hypothesis between SAM and South American Atmospheric Systems suggested above are currently been investigated and it will be presented in a near future.

Previous studies have already indicated the interaction of the SAM phases with the South America atmospheric circulation and in particular their influence on the precipitation patterns (e.g., Silvestri and Vera 2003; Carvalho et al 2005). This work provides further evidence of this relationship showing a link between the Southern Hemisphere cyclone activities with SAM phases. The variability of the South American summer monsoon and the SAM phase is suggested and it also raised some interesting questions. For instance, is the South American LLJ or the SACZ modulated by the SAM phases? Is there any relationship between rainfall extreme events over the southern Brazil and the SAM? However from the present study other important questions were not discussed, for instance, why the precipitation anomalies over South America are not symmetric between the SAM phases? Of course, the atmospheric general circulation is non linear but how is it possible to measure such differences? These are just a few questions that still need to be investigated.

\section{ACKNOWLEDGMENTS}

The authors would like to acknowledge FAPESP (Process Number 04/02446-7), CAPES, and CNPq for the financial support; I. Simmons and K. Keay from University of Melbourne who provided the cyclones/anticyclones tracking scheme, and NCEP for providing the reanalysis data.

\section{REFERENCES}

ADLER, R. F. etal. The version-2 Global Precipitation Climatology Project (GPCP) Monthly Precipitation Analysis (1979present). Journal of Hydrometeorology, v. 4,p. 1147-1167, 2003.

CARVALHO, L. M. V.; JONES, C.; AMBRIZZI, T. Opposite Phases of the Antarctic Oscillation and Relationships with Intraseasonal to Interannual Activity in the Tropics during the Austral Summer. Journal of Climate, v. 18, p. 702-718, 2005.

CARVALHO, L. M. V.; JONES, C.; LIEBMANN, B. The South Atlantic convergence zone: Persistence, intensity, form, extreme precipitation, and relationships with intraseasonal to interannual activity and extreme rainfall. Journal of Climate, v. 17 , p. 88-108, 2004.
GONG, D.; WANG, S. Definition of Antarctic Oscillation index. Geophysical Research Letters, v. 26, p. 459-462, 1999.

HERDIES, D. L.; DA SILVA, A.; SILVA DIAS, M. A.; NIETOFERREIRA, R. Moisture budget of the bimodal pattern of the summer circulation over South America. Journal Geophysical Research, v. 107, p. 42/1-42/10, 2002.

KALNAY, E. et al. NCEP/NCAR 40-year Reanalysis Project. Bulletin of the American Meteorological Society, v. 77, p. 437-471, 1996.

LIEBMANN,B.; KILADIS, G.N.;MARENGO,J.A.;AMBRIZZI, T.; GLICK, J. D. Submonthly convective variability over South America and the South Atlantic convergence zone. Journal of Climate, v. 12, p. 1877-1891, 1999.

LIEBMANN, B; KILADIS. G. N.; VERA, C. S.; SAULO, A. C.; CARVALHO, L. M. V. Subseasonal variations of rainfall in South America in the vicinity of the low-level jet east of the Andes and comparison to those in the South Atlantic convergence zone. Journal of Climate, v. 17(19), p. 3829-3842, 2004.

MARENGO, J. A.; SOARES, W. R.; SAULO, C.; NICOLINI, M. Climatology of the Low-Level Jet East of the Andes as Derived from NCEP-NCAR Reanalyses. Characteristics and Temporal Variability. Journal of Climate, v. 17, n. 12, p. 2261-2280, 2004.

MARSHALL, G. J. Trends in the Southern Annular Mode from Observations and Reanalyses. Journal of Climate, v. 16, p. 4134-4143, 2003:

MURRAY, R. J.; SIMMONDS, I. A numerical scheme for tracking cyclone centers from digital data. Part I: Development and operation of the scheme. Australian Meteorological Magazine, v. 39, p. 155-166, 1991a.

MURRAY, R. J.; SIMMONDS, I. A numerical scheme for tracking cyclone centers from digital data. Part II: Application to January and July general circulation model simulations. Australian Meteorological Magazine, v. 39, p. 167-180, 1991 b.

PETTERSSEN, S. Weather Analysis and Forecasting. 2nd ed., vol. 1, McGRAW-HILL, New York, 1956.

PEZZA, A. B.; AMBRIZZI, T. Variability of the Southern Hemisphere cyclone and anticyclone behavior: Further analysis. Journal of Climate, v. 16, p. 1075-1083, 2003.

ROGERS, J. C.; VAN LOON, H. Spatial variability of sea level pressure and 500-mb height anomalies over the Southern Hemisphere. Monthly Weather Review, v. 110, p. 1375-1392, 1982.

SATYAMURTY, P.; MATTOS, L. F. Climatological lower tropospheric frontogenesis in the midlatitudes due to horizontal deformation and divergence. Monthly Weather Review, v. 117, n. 6, p. 1355-1364, 1989.

SILVESTRI, G. E., VERA, C. S. Antarctic Oscillation signal on precipitation anomalies over southeastern South America. 
Geophysical Research Letters, v. 30, n. 21, p. 3-1 - 3-4, 2003.

SIMMONDS, I.; KEAY, K. Variability of Southern Hemisphere Extratropical Cyclone Behavior, 1958 - 1997. Journal of Climate, v. 13, p. 550 - 561, 2000 a.

SIMMONDS, I.; KEAY, K. Mean Southern Hemisphere Extratropical Cyclone Behavior in the 40-year NCEPNCAR Reanalysis. Journal of Climate, v. 13, p. $873-885$, $2000 \mathrm{~b}$.

THOMPSON, D. W. J. Annular Modes Website - A Brief Introduction to the Annular Modes and Annular Mode Research, 2007. Disponível em $<$ http://ao.atmos.colostate. edu $>$. Acesso em 10 jan. 2008, 16:30.
THOMPSON, D. W. J.; WALLACE J. M. Annular Modes in the Extratropical Circulation. Part I: Month-to-Month Variability, Journal of Climate, v. 13, p. 1000-1016, 2000 a. THOMPSON, D. W. J.; WALLACE, J. M. Annular Modes in the Extratropical Circulation. Part II: Trends. Journal of Climate, v. 13, p. 1018-1036, 2000 b.

VERA, C. S. et al.: Toward a Unified View of the American Monsoon Systems. Journal of Climate - special section, v. 19, p. 4977-5000, 2006.

WILKS, D. S. Statistical Methods in the Atmospheric Sciences. 2nd ed., vol. 1, Academic Press, New York, 2006.

YU, J.-Y.; HARTMANN D. L. Zonal Flow Vacillation and Eddy Forcing in a Simple GCM of the Atmosphere. Journal of the Atmospheric Science, v. 50, p. 3244-3259, 1993. 